\title{
Splenectomy in Patient with Splendid Cysts
}

\author{
Vinícius Moreira Paladino', Thiago Sande Miguel', Débora Trindade Martins', \\ Nayrton Kalys Cruz dos Anjos' ${ }^{1}$ Fernando Antonio Galvão Pereira Junior ${ }^{1}$, \\ Marcia Machado Galvão Pereira ${ }^{1}$, Carolina Galvão Teixeira², Vinicius Sande Miguel ${ }^{3}$, \\ Bruna Sande Miguel $^{3}$, Daniel Almeida da Costa1
}

\author{
${ }^{1}$ The Medical School at the Center of Higher Education of Valença, Valença, Brazil \\ ${ }^{2}$ Suprema Medical School, Juiz de Fora, Brazil \\ ${ }^{3}$ Universidade Grande Rio Medical School, Rio de Janeiro, Brazil \\ Email: professordanielfmv@gmail.com
}

How to cite this paper: Paladino, V.M., Miguel, T.S., Martins, D.T., dos Anjos, N.K.C., Junior, F.A.G.P., Pereira, M.M.G., Teixeira, C.G., Miguel, V.S., Miguel, B.S. and da Costa, D.A. (2018) Splenectomy in Patient with Splendid Cysts. Journal of Biosciences and Medicines, 6, 120-125. https://doi.org/10.4236/jbm.2018.65013

Received: October 14, 2017

Accepted: May 21, 2018

Published: May 24, 2018

Copyright $\odot 2018$ by authors and Scientific Research Publishing Inc. This work is licensed under the Creative Commons Attribution International License (CC BY 4.0).

http://creativecommons.org/licenses/by/4.0/

\section{Open Access}

\begin{abstract}
Introduction: Splenic cysts are uncommon and usually do not generate signs and symptoms, being diagnosed by incidental findings. Case report: A 35-year-old, female patient attended the Luiz Gioseffi Jannuzzi School Hospital (HELGJ) presenting episodes of vomiting and abdominal pain in the left hypochondrium. She was hospitalized for diagnostic investigation. Computed tomography showed the splenic cyst. The procedure was the surgical approach by laparotomy with splenectomy. Histopathological confirmed the diagnosis. Discussion: Compared to the scarce reports in literature, the case described presented typical epidemiology and clinical features. Conclusions: Given the rarity of this pathology cases, it is essential to report these in order to elucidate the specificities and also to discuss diagnostic and therapeutic methods.
\end{abstract}

\section{Keywords}

Splenectomy, Splendid Cysts, Abdominal Pain

\section{Introduction}

Non-parasitic splenic cysts are considered uncommon, with relatively few reports in literature. They are mostly incidental findings during imaging or necropsy studies [1]. They can be classified into two groups according to their characteristics and pathological bases. True splenic cysts have a cellular layer and are probably of congenital (mesothelial or dermoid) or neoplastic origin. On the other hand, the false or pseudocysts have a wall of fibrous tissue, almost always calcified, and it is not covered by a cellular layer, and abdominal trauma is its 
main etiological factor [2].

It occurs more in women, during their second, third and fourth life decades [3]. The clinic presents as some asymptomatic or manifesting symptoms such as pain in the left hypochondrium, left hemithorax, epigastrium and/or periumbilical region, resulting from the compression of adjacent viscera. Vomiting, nausea, early satiety, and postprandial fullness may be associated. In emergency cases, such as in the cyst rupture, triggers signs and symptoms of acute abdomen can be presented [3] [4].

It is usually diagnosed through procedures performed for investigation or therapy of other abdominal conditions, as well as routine physical and radiological examination [2]. The confirmation is made through histopathology, and can be preceded by ultrasound (US) and/or computed tomography (CT), both of the abdomen region, which are performed for possible differential diagnoses [1] [5].

According to the literature, symptomatic splenic cysts should be treated surgically, with splenectomy being the method of choice. Conservative treatment options, such as percutaneous aspiration or sclerosis, do not result in good long-term control. Several studies have indicated the advantages of surgical treatment by video laparoscopy, however, the gold standard for surgical treatment of splenic cysts remains controversial [2] [6] [7].

This paper's objective is to report a case of polycystic spleen in women with curative treatment through laparotomy with splenectomy, highlighting the characteristics of this unusual pathology, as well as the diagnostic and therapeutic procedures available.

\section{Case Report}

Patient T.H.M.E., 35 years old, female, from the city of Valença, State of Rio de Janeiro, attended the Emergency Room (ER) of Luiz Gioseffi Jannuzzi School Hospital (HELGJ) presenting, as a history of the current disease, episodes of vomiting, associated with abdominal pain in the left hypochondrium. Physical examination can detect mass in the Taube space and a large palpable mass in the region.

The patient was admitted to the Medical Clinic for diagnostic clarification. The US showed the presence of multiple cystic images in the spleen (Figure 1 and Figure 2). The finding was complemented and confirmed by CT, which described as "Spleen enlarged by the presence of multiple cystic formations, some with perineal calcifications compromising its middle and lower third, measuring about $10.3 \times 5.1 \mathrm{~cm}$ in the largest cross-sectional diameters", the images of which are shown below (Figure 3 ).

In view of the condition, the patient underwent laparotomy with splenectomy and removed hyperchromic lesion in umbilical scar (this data was described in the surgical report in this way, what inviabilized deeper details. sorry for not having more clarifications) (Figure 4). In anatomopathological analysis it was described: "spleen weighing 405 grams, measuring $17 \mathrm{~cm}$, appearing multiloculate 


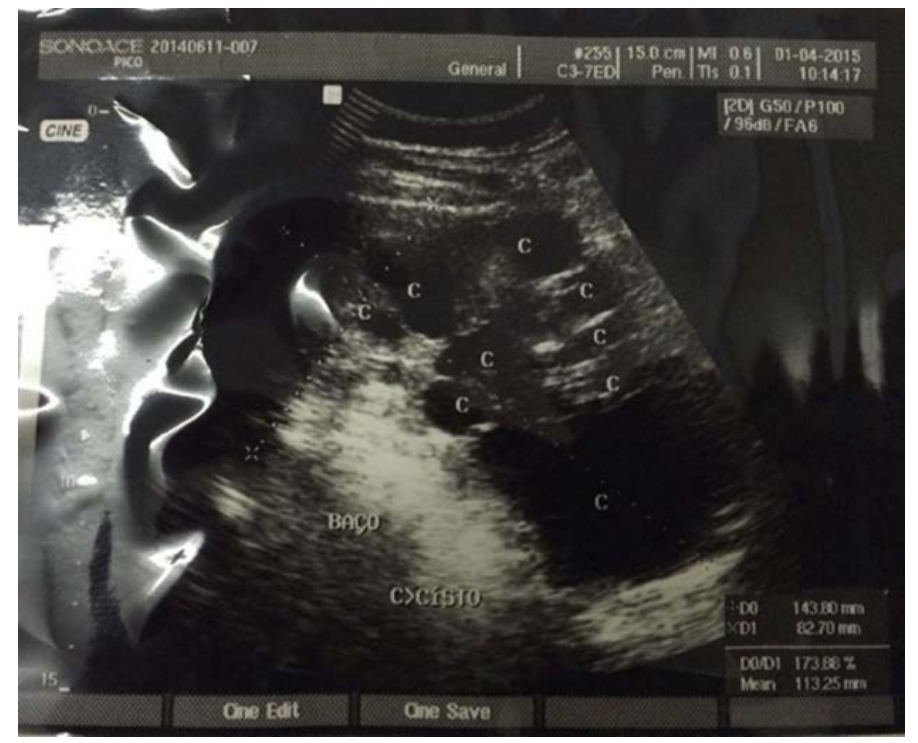

Figure 1. US shows multiple cystic images in spleen.

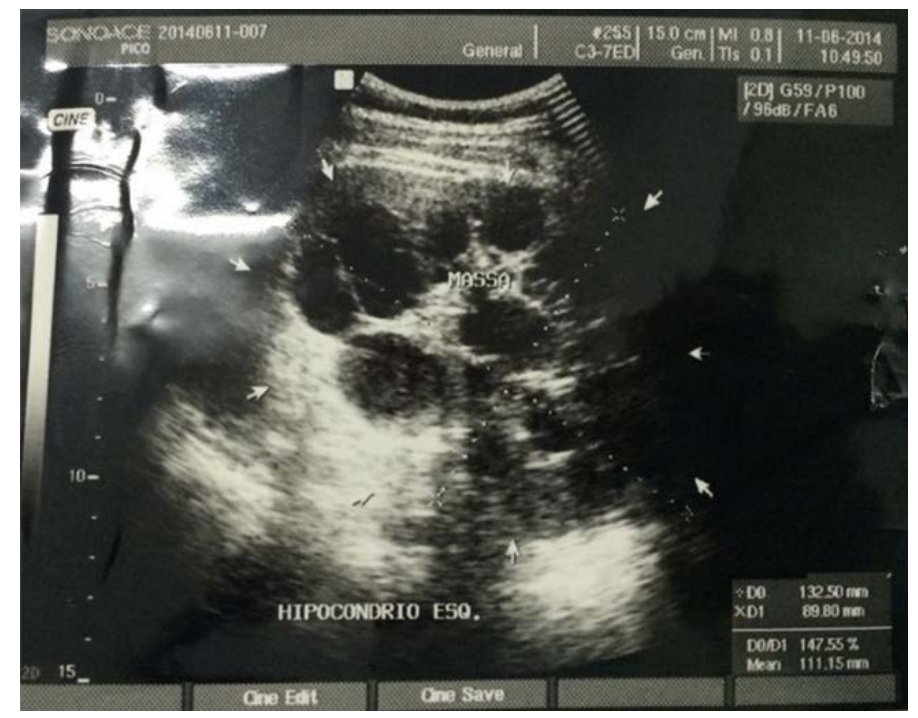

Figure 2. US shows multiple cystic images in spleen.
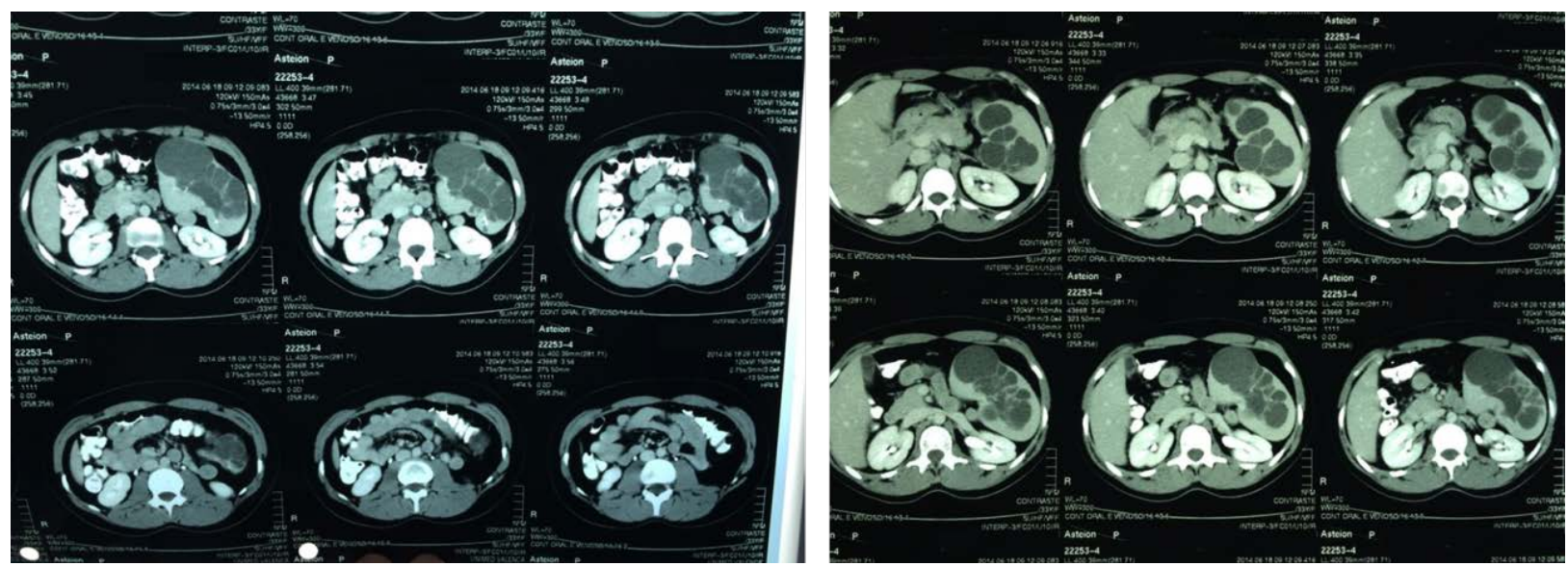

Figure 3. CT: Spleen enlarged by the presence of multiple cystic formations, some with perineal calcifications. 


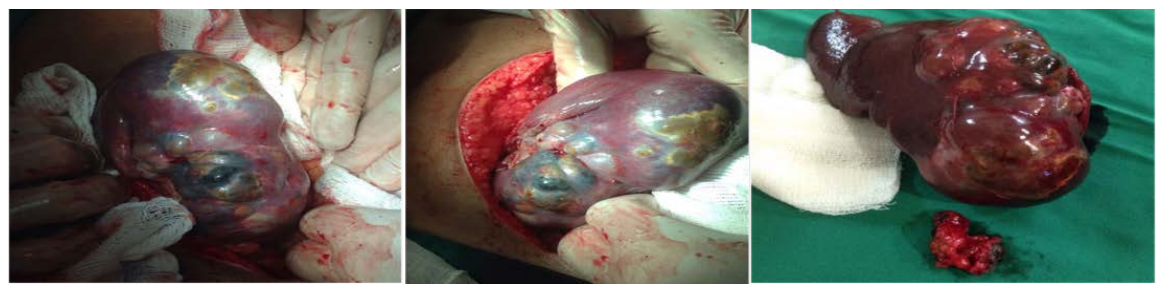

Figure 4. Anatomical part shows spleen with multiloculate cysts.

cysts. Microscopy: multiple cysts coated by cuboid epithelium, with regular nucleus and fibrous wall. As found an injury in umbilical scar, endometrial appearance. Diagnostic conclusion: polycystic spleen and endometriosis". She was discharged on the fifth postoperative day.

It should be noted that the patient of the present study was willing to accept the publication of the present report, after explaining its underlying pathology and its relevance. She signed the Free and Informed Consent Form and, thus, proceeded with the present study.

\section{Discussion}

In general, the prevalence of splenic cysts is higher among women when compared to men, with the age group between the second and third decades of life, being the most affected [8]. The patient described is female and is 35 years old, which is in agreement with those found in literature. Despite this, this case is relevant in view of the restricted amount of reports described, given their rarity.

As for symptomatology, the majority of patients are asymptomatic, but there may be, at rest or physical examination, pain may be present in the left hypochondrium, left hemithorax, epigastrium and/or periumbilical region [9] [10]. And several times, associated with gastrointestinal symptoms, such as early satiety, postprandial fullness, nausea and vomiting [11]. In this case, it was reported as a history of the current disease, episodes of vomiting and abdominal pain in the left hypochondrium region. Physical examination can detect mass in the Traube space and a large palpable mass in the region. Although many pathologies present similar clinical manifestations, the hypothesis that patients were already evolving with splenic cysts, although previously asymptomatic, is strongly considered since the results of US and CT showed multiple nodules in the spleen [5].

Currently, the US and CT are the most requested complementary and indicated by the theoretical basis exams. The latter method is the most sensitive allowing the identification of septa, more frequent in true cysts, and/or calcifications, which would indicate a false cyst [12]. Therefore, there is one more fact that contributes in favor of treating splenic cysts in the case reported above.

Therapy with a surgical approach through laparotomy with splenectomy is the most indicated [13], although currently, for asymptomatic cases and presenting cysts smaller than two centimeters, which do not show calcifications or increased internal or collateral circulation, expectant management is accepted [14] [15]. 
Recent case studies indicate the advantages of video laparoscopy approach (VL) for performing the cyst crackling. This procedure has the purpose of allowing free drainage in the peritoneal cavity so that the fluid is reabsorbed. Another factor that favors this indication is that the splenic tissue is not altered, and there is only the resection of the cyst dome. One point questioned in the VL approach is the high recurrence rate, but with epiploonuse this concern has decreased [6].

\section{Conclusions}

After literature review and the report, the reduced number of cases of splenic cyst described in literature was evidenced.

In summary, the diagnosis is made due to incidental findings during investigations of various pathologies involving the gastrointestinal tract and/or abdominal region. The patient usually presents himself asymptomatic, but in some cases gastrointestinal symptoms may be present. Therapy is a matter of discussion, but laparotomy is still considered in the gold standard. Only in asymptomatic patients with specific cyst characteristics, expectant management can be accepted.

\section{References}

[1] Ingle, S.B., Hinge, C.R. and Patrike, S. (2014) Epithelial Cysts of the Spleen: A Minireview. World Journal of Gastroenterology, 20, 13899. https://doi.org/10.3748/wjg.v20.i38.13899

[2] Alvarez, G.C., Silveira, M.L.D., Costa, E.M.D., Pagliarin, F.V. and Costa, I. (2000) Cisto epidermóide de baço em criança. Arquivos de Gastroenterologia, 37, 69-77. https://doi.org/10.1590/S0004-28032000000100013

[3] Alves, J.G., Estevam, D.L., Santos, J.L.D. and Genn, C.M.S. (1991) Cisto esplênico. Jornal Brasileiro de Medicina, 61, 48-50.

[4] Schlittler, L.A. and Dallagasperina, V.W. (2010) Cistos esplênicos não-parasitários. Revista do Colegio Brasileiro de Cirurgioes, 37, 442-446. https://doi.org/10.1590/S0100-69912010000600011

[5] Rabushka, L.S., Kawashima, A. and Fishman, E.K. (1994) Imaging of the Spleen: CT with Supplemental MR Examination. Radiographics, 14, 307-332. https://doi.org/10.1148/radiographics.14.2.8190956

[6] Pitombo, M.B., Leal, P.R.F. and Albuquerque, R.M.D. (2000) Abordagem videolaparoscópica de cisto esplênico não parasitário. Revista do Colegio Brasileiro de Cirurgioes, 27, 350-351. https://doi.org/10.1590/S0100-69912000000500013

[7] Guerra, M.R.V., Ribeiro, M.A., Nam, M.F., Casale, A.L.V., Martins, C.P.B., Morais, C.E.L.D., et al. (2012) Cisto esplênico não parasitário-tratamento por laparoscopia. Diagnóstico \& Tratamento, 17, 51-55.

[8] Kang, S.I. and Jeon, S.Y. (2013) Primary Non-Parasitic Splenic Cyst: A Case Report. Korean Journal of Hepato-Biliary-Pancreatic Surgery, 17, 139-141. https://doi.org/10.14701/kjhbps.2013.17.3.139

[9] Rana, A.P.S., Kaur, M., Singh, P., Malhotra, S. and Kuka, A.S. (2014) Splenic Epidermoid Cyst-A Rare Entity. Journal of Clinical and Diagnostic Research, 8, 175. https://doi.org/10.7860/JCDR/2014/6901.4050 
[10] Cianci, P., Tartaglia, N., Altamura, A., Fersini, A., Vovola, F., Sanguedolce, F., et al. (2016) A Recurrent Epidermoid Cyst of the Spleen: Report of a Case and Literature Review. World Journal of Surgical Oncology, 14, 98. https://doi.org/10.1186/s12957-016-0857-x

[11] Baier, A., Abreu, P., de Campos, M., Casani, J., Ferreira, L. and Dummer, C. (2017) Pseudocisto esplênico não parasítico: um relato de caso. Clinical \& Biomedical Research, 37, No. 2. https://doi.org/10.4322/2357-9730.71786

[12] Torresa, B.M., Garcíab, M.M., Antac, M.Á.Z., Muñoz-Najard, A.J.G. and Dovaoe, J.C.T. (2017) Giant Splenic Cyst in a Teenage Girl. Case Report. Revista Chilena de Pediatria, 88, 388-392.

[13] Palermo, M., Blanco, L., Acquafresca, P., Menendez, J. and Garcia, R. (2015) Reduce Port Laparoscopic Splenectomy For Giant Epitelial Cyst. Arquivos Brasileiros de Cirurgia Digestiva, 28, 282-285. https://doi.org/10.1590/s0102-6720201500040016

[14] Kenney, C.D., Hoeger, Y.E., Yetasook, A.K., Linn, J.G., Denham, E.W., Carbray, J. and Ujiki, M.B. (2014) Management of Non-Parasitic Splenic Cysts: Does Size Really Matter? Journal of Gastrointestinal Surgery, 18, 1658-1663. https://doi.org/10.1007/s11605-014-2545-X

[15] Navarini, D., Aita, L.N., Fleck, F.P.D.A., Madalosso, C.A.S., Moraes Junior, I.D.S. and Fornari, F. (2010) Cisto Epidermóide de Baço em paciente previamente hígido. Revista HCPA. Porto Alegre, 30, 192. 